New North Star, 2020; 2:66-68

\title{
Placing the Oratory of Frederick Douglass in Time and Space
}

\section{Owen J. Dwyer \\ IUPUI}

The Frederick Douglass Papers (FDP) is mapping the location of Douglass's public speaking engagements. Supported by grants from IUPUI's Center for Research and Learning and the Institute of American Thought, student researchers have been scouring the Douglass Papers' archive for information about where and when he delivered public addresses. To date, researchers have examined thirty-one years from Douglass's public career. They have presented their results at student research gatherings hosted by IUPUI and Butler University. Carefully recorded in a spreadsheet's cells and subsequently plotted on a map, the results of this vast compilation, "An Atlas of the Oratory of Frederick Douglass," eventually will be shared at the project's website. Projected for release in 2023, this online exhibit will complement existing Douglass scholarship by presenting an interactive map that allows users to explore the spatial dimension of Douglass's far-reaching intervention in American life.

The immediate inspiration for the project derives from our former colleague Caitlin Pollock's digital map of Ida B. Wells's anti-lynching activism. Pollock's map clearly illustrates lynching's spatial distribution and the focus of Wells's subsequent activism. Working by analogy from Wells's career suggested the value of applying a similar technique to Douglass's oratory. Decades of scholarship have revealed themes and patterns in Douglass's speeches; what might be learned from mapping the places where he addressed the public?

The project began in earnest at IUPUI in 2016 when researchers-undergraduate and graduate research assistants drawn from a diverse collection of majors and disciplines - began examining archival sources housed at the Douglass Papers, seeking out references to the site and situation of his public addresses. Each research assistant was assigned one of Douglass's fifty-six years of public oratory and tasked with carefully recording data related to the time and place of his speeches. Within their assigned year, researchers combed through the Douglass Papers' vast collection of nineteenth-century newspaper clippings about Douglass and its holdings of his correspondence, editorials, and other writings, gleaning relevant data along the way. A "data dictionary" imposed a strict format for entering dates and places, ensuring that all researchers recorded information in a uniform manner and a format adaptable to the production of tables and maps.

The facts recorded about each of Douglass's presentations fall into three categories: itinerary, venue, and event. Details associated with his itinerary include his point of origin and destination(s), mode of travel, and any overnight accommodations. Care is taken to note any evidence of racial discrimination in mode of travel or accommodations. Relevant aspects of the venue include the city, street address, name of building or public place, and capacity. Event details include the demographic makeup of the audience, lecture topic, sponsoring organization, fellow speakers, remuneration, and any notes that can be used to characterize the event. Later, researchers compiled the latitude and longitude coordinates of the presentation's venue and added it to the database. These coordinates are useful in cases where street addresses have changed, buildings have been demolished, or streets rerouted. Their inclusion allows us to accurately locate Douglass's presentations on the map. 
Beginning in 1839 in New Bedford, Massachusetts, and ending with his final public address in Washington, D.C., in February of 1895, Douglass delivered thousands of scheduled and spontaneous presentations. At the beginning of his career, Douglass spoke to small northeastern audiences in places closely associated with the nascent abolitionist movement. In support of his newspaper and cause, backed by a movement and its sponsors, Douglass's circuit grew to include large and small cities north of the Ohio River. Throughout this antebellum period, he needed to remain cognizant of places where the Fugitive Slave Acts were actively enforced and be on the watch for political opponents and hostile mobs. During the Civil War, he spoke throughout the North, mixing his political activism (e.g. advocating for broader war goals) with his work recruiting for the army. After the war, he ranged even more widely on behalf of the nascent civil rights movement and Republican Party causes, and in financial support of his family as a popular figure on the professional lecture circuit. Over the course of his six-decade speaking career, the size of Douglass's audiences increased, and he spoke as far west as Denver; as far south as New Orleans, Louisiana; and more than one hundred times outside of the country, most famously in Ireland and Great Britain.

Eventually, the atlas will act as a reference work for heretofore unwieldy, seemingly prosaic empirical questions. Where, for instance, did Douglass speak most often? For that matter, what is the total number of his speaking engagements? What was the largest audience to witness his oratory? On how many occasions did he speak in the former slave states? When we sort these engagements by year and location, what, if any, patterns are apparent? How might we explain them? In its capacity as a reference source, our intention is that the atlas will serve a broad audience of student and professional scholars.

In addition to contributing to the knowledge base of Douglass scholarship, plotting his speaking engagements on the changing map of nineteenth-century America may prompt new research questions related to Douglass's oratory. For instance, did his subjects and rhetorical techniques vary from place to place? What, if any, impact can be attributed to the racial and gender composition of his audience? How did the composition of his audience vary geographically? More generally, can we discern any regional patterns in his oratory, e.g. Did his message vary in New York City compared to Chicago? Or, to shift the comparative frame, how does the map of his speaking engagements fit with the activities of his various rivals and opponents, e.g. Garrisonian abolitionists, fugitive slave hunters, or the American Colonization Society?

Finally, the atlas database may help scholars further understand the significance of Douglass in this historical context. Take for instance the socio-political significance of Douglass's famed mobility. Beginning with northward self-emancipation and continuing on through his late career comings and goings from his Anacostia home, Douglass's mobility was simultaneously representative and exceptional from the experiences of contemporary African Americans. What do the conditions of Douglass's mobility indicate about the more general condition of Black freedom between the fall of the Slave Power and the rise of Jim Crow? Are there similarities among maps of his speaking engagements and the Underground Railroad? African American religious congregations or Republican voters and clubs? Thus, we intend that the atlas help us investigate White supremacy's enduring obsession with regulating Black mobility.

Throughout his career, Douglass sought out audiences ready to support the causes he championed: abolition, emancipation, and an expansive franchise. Broadly, the dates and places of Douglass's speaking career describe a geography of progressive nineteenth-century America. As a database compiling the facts of where and when he spoke, the message he delivered, and who attended those events, "An Atlas of the Oratory of Frederick Douglass" intends to provide scholars 
Owen J. Dwyer

with a convenient reference work, one that simultaneous answers empirical questions and inspires ongoing critical inquiry into Douglass's enduring impact. 